\title{
Рассмотрение ходатайств о помимовании в Российской Федерации: новации 2020 г.
}

\section{В. И. СЕЛИВЕРСТОВ}

Московский государственный университет им. М. В. Ломоносова, г. Москва, Российская Федерация; Московский государственный лингвистический университет, г. Москва, Российская Федерация

ORCID: https://orcid.org/0000-0002-9554-5438, e-mail: vis_home@list.ru

Р е фер ат

Введение: в статье анализируются внесенные указом Президента Российской Федерации от 14.12.2020 № 797 изменения в указ Президента Российской Федерации от 28.12.2001 № 1500 «О комиссиях по вопросам помилования на территориях субъектов Российской Федерации» и нормы нового Положения о порядке рассмотрения ходатайств о помиловании в Российской Федерации. Методы: сравнительно-правовой метод и метод толкования юридических норм. Результаты: по итогам анализа нормативной регламентации деятельности комиссий и рассмотрения ходатайств осужденных о помиловании к числу позитивных изменений автором отнесены: увеличение срока ротации членов комиссий по вопросам помилования; уточнение их аналитических и контрольных функций; включение социальной адаптации в число обстоятельств, учитываемых при рассмотрении вопроса о помиловании; исключение опубликования в средствах массовой информации анкетных данных лиц, рекомендованных к помилованию высшим должностным лицом субъекта Российской Федерации; учет мнения потерпевших от преступления. Негативными представляются те изменения, которые породили новые проблемы в виде противоречий с нормами уголовного и уголовно-исполнительного законодательства. В их числе - возможность применения помилования к лицам, отбывающим иные меры уголовно-правового характера, и обращение с ходатайством о помиловании непосредственно в комиссию по вопросам помилования, минуя администрацию учреждений и органов, исполняющих наказания. Вывод: актуальная в настоящее время задача расширения практики помилования не может быть решена посредством принятия нового Положения о порядке рассмотрения ходатайств о помиловании в Российской Федерации.

Ключевы е с лов а : уголовное законодательство; уголовно-исполнительное законодательство; осужденный; помилование; уголовное наказание; иные меры уголовно-правового характера; Президент Российской Федерации; комиссии по вопросам помилования.

12.00.08 - Уголовное право и криминология; уголовно-исполнительное право.

Для цити ров ания: Селиверстов В. И. Рассмотрение ходатайств о помиловании в Российской Федерации: новации 2020 г. Пенитенциарная наука, 2021, т. 15, № 1 (53), с. 33-42. DOI 10.46741/2686-9764-2021-15-1-33-42.

\section{Consideration of Petitions for Pardon in the Russian Federation: Novelties of 2020}

VYACHESLAV I. SELIVERSTOV

Lomonosov Moscow State University, Moscow, Russian Federation; Moscow State Linguistic University, Moscow, Russian Federation

ORCID: https://orcid.org/0000-0002-9554-5438, e-mail: vis_home@list.ru

A b s t r a c t. Introduction: the paper analyzes the amendments made by the Decree of the President of the Russian Federation no. 797 of December 14, 2020 to the Decree of the President of the Russian Federation of December 28, 2001 no. 1500 "On commissions for pardon in the territories of constituent entities of the Russian Federation" and the norms 
of the new Regulation on the procedure for considering petitions for pardon in the Russian Federation. Methods: comparative legal method and method of interpretation of legal norms. Results: having analyzed legal documentation on the activities of the commissions and having considered convicts' petitions for pardon, we point out the following positive changes: an increase in the rotation period of members of the commissions for pardon; clarification of their analytical and control functions; inclusion of social adaptation in the number of circumstances taken into account when considering the issue of pardon; exclusion of personal data of individuals recommended for pardon by the highest official of a constituent entity of the Russian Federation from publication in the mass media; taking into account the opinions of the victims of the crime. We think that negative changes are those that have created new problems in the form of contradictions with the norms of criminal and penal legislation. These include the possibility of granting pardon to persons serving other criminal law measures, and applying for pardon directly to the commission on pardons, bypassing the administration of institutions and bodies that execute sentences. Conclusion: the current task to expand the practice of granting pardon cannot be solved by adopting a new Regulation on the procedure for considering petitions for pardon in the Russian Federation.

Keywords: criminal legislation; penal legislation; convict; pardon; criminal punishment; other measures of a criminal legal nature; President of the Russian Federation; commissions on pardons.

12.00.08 - Criminal law and criminology; penal law.

F or c it ation: Seliverstov V.I. Consideration of petitions for pardon in the Russian Federation: novelties of 2020. Penitentiary Science, 2021, vol. 15, no. 1 (53), pp. 33-42. DOI 10.46741/2686-9764-2021-15-1-33-42.

\section{Введение}

Конституцией Российской Федерации предусмотрены право каждого лица просить о помиловании (ч. 3 ст. 50) и полномочие главы государства по осуществлению помилования (ст. 89). Формы помилования применительно к уголовно-правовой сфеpe, а также принципиальные положения о том, что, во-первых, помилование возможно только в отношении лиц, отбывающих уголовные наказания, во-вторых, оно носит строго индивидуальный характер, установлены в нормах уголовного законодательства (ст. 85 УК РФ). Основания освобождения, порядок подачи ходатайства и освобождения от отбывания наказания по акту помилования предусмотрены в нормах уголовно-исполнительного законодательства (ст. 172, 173 и 176 УИК РФ).

Законодательную регламентацию применения помилования дополняет подзаконное регулирование. Так, в течение девятнадцати лет в нашей стране действовало утвержденное указом Президента Российской Федерации от 28.12.2001 № 1500 Положение о порядке рассмотрения ходатайств о помиловании в Российской Федерации. Неоднократно в него вносились изменения и дополнения, однако это не избавляло осуществляемую на его основе практику применения помилования от критических оценок правозащитников, которые через Совет при Президенте Российской Федерации по развитию гражданского общества и правам человека и Уполномоченного по правам человека в Российской Федерации ежегодно ставили вопрос о корректировке указанной практики в сторону расширения. По итогам одного из обсуждений Президент Российской Федерации в феврале 2019 г. поручил своей администрации, Министерству юстиции Российской Федерации, Общественной палате Российской Федерации, федеральному омбудсмену и властям регионов разработать предложения, направленные на совершенствование процедуры формирования и деятельности региональных комиссий по вопросам помилования и повышение эффективности их функционирования. В итоге этой работы указом Президента Российской Федерации от 14.12.2020 № 797 были внесены изменения и дополнения в указ Президента Российской Федерации от 28.12.2001 № 1500 «О комиссиях по вопросам помилования на территориях субъектов Российской Федерации» и утверждено новое Положение о порядке рассмотрения ходатайств о помиловании в Российской Федерации.

Каковы же новации в регулировании деятельности комиссий и порядка рассмотрения ходатайств о помиловании в России и какими факторами они обусловлены? Ответим на данные вопросы, сопоставив по- 
ложения отмененных и новых нормативных актов.

Первый блок - это изменения и дополнения, направленные на совершенствование редакции норм и отчасти на устранение правовых неточностей. К ним следует отнести указание на то, что судимость должна быть не только неснятой, но и непогашенной (п. 2 указа и п. 1-3, 17 положения), а также на то, что осужденные судами иностранного государства могут отбывать наказание на территории Российской Федерации не только на основании международных договоров, но и на условиях взаимности (п. 3 положения).

К этому же блоку относится унификация сроков направления: а) территориальным органом уголовно-исполнительной системы - ходатайства осужденного в комиссию по вопросам помилования (п. 12); б) администрацией исправительного учреждения и иных государственных органов - ответов на запрос высшего должностного лица субъекта Российской Федерации или комиссии по вопросам помилования (п. 20).

На наш взгляд, не имеет принципиального значения исключение обязанности территориального органа УИС информировать ФСИН России о поступивших ходатайствах осужденных (п. 12), так как при необходимости этот момент можно предусмотреть в управленческих нормативах самой УИС.

Второй блок изменений коснулся формирования и функционирования комиссий по вопросам помилования в субъектах Российской Федерации.

Так, было установлено, что состав комиссии обновляется на одну треть один раз в пять лет. Ранее этот срок составлял два года. На практике указанное положение о смене одной трети состава комиссии касалось преимущественно той части ее членов, которые являлись представителями общественности, поскольку треть членов комиссии, которая формировалась за счет должностных лиц, как правило, была более стабильной. Увеличение сроков ротации вполне объяснимо.

Во-первых, в последние десятилетия произошло сокращение числа прошений осужденных о помиловании. Смена одной трети состава комиссии один раз в два года в таких условиях не позволяла членам комиссии глубоко вникнуть в механизм помилования, уяснить его социально-правовое назначение и обеспечить необходимую степень объективности и профессионализма при реализации этой важной государственной функции.

Во-вторых, желающих заниматься этой общественной деятельностью в субъектах Российской Федерации оказалось не столь много, чтобы менять их в довольно короткие сроки. Эта же проблема обусловила увеличение срока полномочий общественных наблюдательных комиссий с двух до трех лет в 2010 г. Как свидетельствует зарубежный опыт, например практика деятельности визитеров в тюрьмах Великобритании, для успешной общественной работы необходим достаточно высокий уровень материального благополучия населения, как минимум сформированный средний класс, представители которого могут выполнять общественную работу, не опасаясь ухудшения своего материального положения. Поэтому комплектование общественного сектора комиссии по вопросам помилования в нашей стране связано с определенными трудностями.

В-третьих, положение о ротации на одну треть один раз в два года сразу было негативно воспринято председателями комиссий по вопросам помилования, что показало обсуждение практики помилования на всероссийских совещаниях данных руководителей в Московской области (2002 г.) и г. Нижнем Новгороде (2003 г.).

Также были скорректированы задачи комиссий по вопросам помилования. Ранее довольно серьезные нарекания вызывала содержавшаяся в указе № 1500 задача по осуществлению общественного контроля за своевременным и правильным исполнением на территории субъекта Российской Федерации указов Президента Российской Федерации по вопросам помилования, а также за условиями содержания осужденных [10, с. 94]. Дело в том, что реальных правовых механизмов для осуществления общественного контроля комиссиями по вопросам помилования в законодательстве не закреплено, на что неоднократно указывалось правозащитниками [1, с. 88-89]. Отсутствовали они и в действовавшем ранее Положении о порядке рассмотрения ходатайств о помиловании в Российской Федерации, утвержденном указом № 1500. В новой редакции данная задача сформулирована не столь амбициозно, но точно - как осуществление контроля за соблюдением права лица просить о помиловании. При 
анализе данного нововведения обращают на себя внимание два аспекта.

Во-первых, то, что из формулировки задачи исчезло определение контроля как общественного. Видимо, было учтено то положение, что не менее трети членов комиссии формируется из числа должностных лиц органов государственной власти и органов местного самоуправления. Однако из истории советского периода развития нашего государства известен аналогичный порядок формирования наблюдательных комиссий, которые тем не менее согласно нормам ИТК РСФСР осуществляли общественный контроль. Кроме того, исключение из задачи указания на общественный контроль не способствовало решению вопроса, о каком виде контроля идет речь - государственном или ином. А от ответа на него зависит многое, в том числе выбор форм и методов осуществления контроля.

Второй аспект заключается в том, что опять проявился недостаток, который был свойственен прежним нормативным документам в сфере осуществления помилования, а именно: ни в указе, ни в положении не определены формы и методы осуществления такого контроля, не прописаны права комиссий по осуществлению контроля и обязанности должностных лиц по оказанию содействия комиссиям по вопросам помилования в реализации контрольной деятельности и реагировании на ее результаты.

В новой редакции указа сохранена задача комиссий по вопросам помилования, связанная с аналитической работой. До 2020 г. соответствующая деятельность заключалась в подготовке предложений о повышении эффективности деятельности учреждений и органов УИС и иных государственных органов, находящихся на территории субъекта Российской Федерации, в сфере помилования осужденных, а также социальной адаптации лиц, отбывших наказание. В соответствии с указом Президента Российской Федерации от 14.12.2020 № 797 на комиссию по вопросам помилования возложена задача подготовки предложений о повышении эффективности взаимодействия учреждений и органов УИС, иных государственных органов, органов местного самоуправления, находящихся на территории субъекта Российской Федерации, по вопросам помилования осужденных, а также социальной адаптации лиц, отбывших наказание. При этом нормативное регулирование помилования, как и в случае с осуществлением контроля за соблюдением права лица просить о помиловании, не содержит организационно-правовых гарантий для проведения такой аналитической работы. В частности, Положение о порядке рассмотрения ходатайств о помиловании в Российской Федерации предусматривает право комиссии запросить дополнительные материалы к поступившему ходатайству осужденного о помиловании, но возможность запрашивать данные взаимодействия учреждений и органов УИС, иных государственных органов, органов местного самоуправления, находящихся на территории субъекта Российской Федерации, по вопросам помилования осужденных, а также социальной адаптации лиц, отбывших наказание, в документе не закреплена. А без этого трудно подготовить обоснованные предложения о совершенствовании взаимодействия.

Еще большие новации отличают новое Положение о порядке рассмотрения ходатайств о помиловании в Российской Федерации. В п. 3 анализируемого документа установлено, что в Российской Федерации помилование применяется:

a) в отношении лиц, осужденных судами в Российской Федерации к наказаниям, предусмотренным уголовным законом, и отбывающих наказание на территории Российской Федерации;

б) в отношении лиц, осужденных судами иностранного государства, отбывающих наказание на территории Российской Федерации в соответствии с международными договорами Российской Федерации или на условиях взаимности;

в) в отношении лиц, освобожденных условно-досрочно, в течение оставшейся неотбытой части наказания;

г) в отношении лиц, условно осужденных, а также лиц, которым суды Российской Федерации отсрочили отбывание наказания;

д) в отношении лиц, отбывших назначенное судами наказание и имеющих неснятую или непогашенную судимость.

Таким образом, по сравнению с ранее действовавшим перечнем возникли новые категории осужденных, которые могут подавать ходатайство о помиловании и рассчитывать на его удовлетворение. Цель появления указанных в п. «В» и «Г» категорий осужденных вполне ясна: это вызвано намерением расширить практику применения помилования. Дело в том, что начиная 
с 2001 г. в обозначенной сфере произошли существенные изменения. Так, если в 2000 г. помилование было применено в отношении 12836 осужденных, то уже в 2001 г. - только в отношении 27 осужденных, то есть имело место резкое сокращение в 475 раз. С 2002 по 2012 г. количество помилованных колебалось от 0 до 283, а с 2013 по 2019 г. - от 2 до 7 в год (2013 г. - 5, 2014 г. - 2, 2015 г. - 2, 2016 г. - 6, 2017 г. - 4, 2018 г. - 5, 2019 г. - 7). В 2020 г., согласно данным официального сайта Президента Российской Федерации, было помиловано 5 чел. [2]

Однако при всей очевидности факторов, обусловивших расширение перечня категорий, не вполне понятна юридическая чистота предлагаемых изменений.

В соответствии с ч. 2 ст. 85 УК РФ актом помилования лицо, осужденное за преступление, может быть освобождено от дальнейшего отбывания наказания. Вместе с тем согласно ст. 79 УК РФ при условно-досрочном освобождении лицо уже освобождено от дальнейшего отбывания наказания. Допускается ли дважды (сначала постановлением суда, а потом актом помилования) освободить осужденного от дальнейшего отбывания наказания? Представляется, что это правовой нонсенс. Видимо, с введением новых категорий для помилования предполагалось освободить осужденного от соблюдения условий, которые перечислены в ч. 7 ст. 79 УК РФ, и от исполнения обязанностей, определенных судом на основании ч. 2 ст. 79 УК РФ. Но тогда при помиловании осужденный будет освобождаться от применения иной меры уголовно-правового характера, которая наказанием не является.

Похожие ассоциации вызывает и распространение помилования на лиц, которые на основании ст. 73 УК РФ осуждены к уголовному наказанию условно с испытательным сроком. Согласно ч. 1 ст. 73 УК РФ при условном осуждении осужденный реально не отбывает наказание, поэтому его нельзя от этого освободить. Опять же, актом помилования можно освободить осужденного от выполнения возложенных на него условий и обязанностей, однако они реализуются в рамках иной меры уголовно-правового характера, а не наказания. Освобождение от отбывания иной меры уголовно-правового характера в порядке помилования ч. 2 ст. 85 УК РФ не предусмотрено. Конечно, следует учесть то, что в науке уголовного права имелась точка зрения об отнесении услов- ного осуждения к уголовным наказаниям [13, с. 102-105]. В современный же период большинство ученых считают этот институт иной мерой уголовно-правового характера [4, с. 83-92]. Однако даже при наличии дискуссионных точек зрения на юридическую природу условного осуждения следует исходить из перечня наказаний, приведенного В СТ. 44 УК РФ. В нем условного осуждения нет.

Сходные мысли возникают, если проанализировать предусмотренную новым положением возможность применения акта о помиловании к лицам, которым предоставлена отсрочка отбывания наказания. В эту категорию осужденных в числе других попадают лица, больные наркоманией. Согласно ч. 3 ст. 82.1 УК РФ после прохождения курса лечения от наркомании, медицинской реабилитации, социальной реабилитации и при наличии объективно подтвержденной ремиссии, длительность которой после окончания лечения, медицинской реабилитации, социальной реабилитации составляет не менее двух лет, суд освобождает осужденного, признанного больным наркоманией, от отбывания наказания или оставшейся части наказания. И вновь повторяется та же правовая ситуация. От дальнейшего отбывания наказания по акту помилования освободить невозможно, так как лицо уже освобождено судом, а от лечения и медицинской реабилитации досрочно освобождать, мягко выражаясь, неразумно. При решении этого вопроса необходимо медицинское заключение специалистов о том, что цели такой отсрочки достигнуты, однако положение не предусматривает его получения. Опять же, освобождение на основании акта о помиловании от иных мер уголовно-правового характера не предусмотрено уголовным законом.

В п. 4 нового положения перечислены категории осужденных, к которым помилование, как правило, не применяется. На наш взгляд, указанная норма является излишней. Во-первых, непонятно, к кому она обращена. Субъектом удовлетворения ходатайства осужденного о применении помилования является исключительно Президент Российской Федерации. В соответствии с п. 23-25 нового положения он одновременно является субъектом отклонения ходатайства о помиловании. На всех стадиях прохождения ходатайства (комиссия по вопросам помилования, высшее 
должностное лицо субъекта Российской Федерации) принимаются лишь рекомендательные решения, окончательное же остается за Президентом Российской Федерации. При этом он не связан положительной или отрицательной рекомендацией комиссии и (или) высшего должностного лица. Исходя из этого получается, что рассматриваемая норма обращена к Президенту Российской Федерации. Едва ли целесообразно ему напоминать самому себе о том, какие категории осужденных не подлежат помилованию.

Во-вторых, применение помилования сугубо индивидуально, и регламентировать его подобными ограничениями в усмотрении Президента Российской Федерации означает не только необоснованно ограничивать его конституционные полномочия, но и снижать эффективность института помилования. Жизненные ситуации бывают достаточно разнообразными, и они затрагивают в том числе осужденных, которые перечислены в п. 4 положения. Именно поэтому запрет на применение помилования предусматривает возможность исключений (в виде слов «как правило»). В этом случае регулирующая роль п. 4 положения предельно снижается.

С учетом негативного отношения к п. 4 в целом проанализируем немногочисленные изменения в указанной норме, изложенной в следующей редакции:

«Помилование, как правило, не применяется в отношении осужденных:

а) совершивших умышленное преступление в период назначенного судами испытательного срока условного осуждения;

б) злостно нарушающих установленный порядок отбывания наказания;

в) ранее освобождавшихся от отбывания наказания условно-досрочно;

г) которым ранее производилась замена назначенного судами наказания более мягким наказанием и которые снова совершили преступление;

д) к которым ранее применялись акты об амнистии и (или) акты помилования».

Изменения коснулись подп. «Г» И «Д». В первом случае за счет добавления слов «и которые снова совершили преступление» значительно сужена категория лиц, к которым не рекомендуется применять помилование; во втором случае, наоборот, имеет место расширение: если прежде не рекомендовалось применение помилования $\mathrm{k}$ лицам, ранее освобождавшимся от отбывания наказания по амнистии или акту по- милования, то теперь не рекомендуется помилование в отношении и тех лиц, к которым применялись иные меры смягчения их участи, предусмотренные ст. 84 и 85 УК РФ, освобождение от уголовной ответственности, замена наказания более мягким, сокращение наказания, снятие судимости.

В ранее действовавшем положении было установлено, что ходатайство о помиловании в виде снятия судимости направляется заявителем самостоятельно в комиссию по месту своего жительства. В новом положении к месту жительства вполне обоснованно добавлено место пребывания (п. 13). Кроме того, это правило распространено на направление прошений о помиловании лицами, освобожденными условно-досрочно, и лицами, которым штраф назначен в качестве основного наказания. В п. 14 положения установлен минимум документов, которые должны быть представлены заявителями, а также закреплена возможность комиссии по вопросам помилования запросить дополнительные документы и сведения, необходимые для подготовки и рассмотрения поступивших от осужденных ходатайств. Сопоставление данной нормы с другими нормами положения приводит к выводу о том, что осужденные, отбывающие иные (кроме штрафа) наказания, а также осужденные условно или с отсрочкой наказания свои ходатайства о помиловании подают через администрацию учреждений и органов, исполняющих наказания (п. 6), которая обеспечивает сбор и представление необходимых документов, включая характеристику осужденного, содержащую сведения о его поведении, отношении к учебе и труду во время отбывания наказания, отношении к совершенному деянию (п. 8).

В отношении условно-досрочного освобождения, видимо, учли тот факт, что специализированный федеральный орган, на который ч. 6 ст. 79 УК РФ возложен контроль за поведением соответствующей категории лиц, так и не создан. Однако в этой же норме указано, что контроль за условно-досрочно освобожденным военнослужащим осуществляется командованием воинской части и учреждения. Такое командование в реальности существует и, несомненно, заинтересовано в том, чтобы охарактеризовать поведение военнослужащего, условно-досрочно освободившегося из дисциплинарной воинской части и подавшего ходатайство о помиловании. 
Аналогична ситуация и с подачей ходатайства осужденным к наказанию в виде штрафа. Согласно ч. 1 ст. 16 УИК РФ наказание в виде штрафа исполняется судебными приставами-исполнителями по месту жительства (работы) осужденного. Почему же осужденный самостоятельно обращается в комиссию по вопросам помилования? Такой порядок только увеличит время рассмотрения обращения, поскольку комиссия вынуждена будет запрашивать необходимые материалы у судебных приставов-исполнителей, относящихся к Федеральной службе судебных приставов. Кроме того, возможность самостоятельной подачи осужденным к штрафу ходатайства о помиловании непосредственно в комиссию противоречит ст. 176 УИК РФ, в которой установлено, что ходатайство о помиловании осужденный подает через администрацию учреждения или органа, исполняющего наказание. Никаких исключений этой статьей закона не предусмотрено.

Произошли изменения и в обстоятельствах, которые следует учитывать при рассмотрении ходатайств о помиловании. В соответствии с подп. «ж» п. 21 положения к ним стали относиться не только данные о личности осужденного (состояние здоровья, количество судимостей, семейное положение, возраст), но и возможность его ресоциализации. Этот показатель важен для принятия решения о помиловании в виде освобождения от отбывания наказания, в первую очередь связанного с изоляцией от общества. Представляется, что при оценке возможности ресоциализации должна оцениваться степень сохранности и (или) восстановления социально полезных связей осужденного, выражающаяся:

а) в наличии у лица, претендующего на помилование, постоянного места проживания после освобождения (на арендованной или собственной жилой площади, в реабилитационном центре субъекта Российской Федерации, религиозном культовом учреждении, например монастыре, и т. д.);

б) возможности гарантированного трудоустройства после освобождения, подтвержденного документами коммерческих и некоммерческих организаций и (или) органов местного самоуправления;

в) поддержании или восстановлении духовной связи с семьей, детьми и близкими родственниками (заключение брака, переписка, телефонные разговоры, свидания и видеосвидания); г) материальной поддержке осужденного семьей или близкими родственниками либо, наоборот, осужденным семьи или близких родственников (получение и отправление денежных переводов, бандеролей, посылок и передач);

д) получении профессии (повышение квалификации), общего образования;

е) повышении культурного уровня, расширении кругозора, раскрытии творческих способностей, которые могут стать после освобождения основой правопослушного поведения;

ж) стремлении к избавлению от вредных привычек и излечению от социально опасных заболеваний (алкоголизма, наркомании, токсикомании, венерических заболеваний, педофилии, туберкулеза и психических расстройств);

з) надлежащем уходе за ребенком осужденной женщиной в доме ребенка при исправительном учреждении и т. п. [15, с. 100].

Это именно те ценности, обладание которыми может помочь после освобождения по акту помилования закрепиться в обществе и вести правильный образ жизни.

В юридической литературе представлены различные мнения по вопросу о субъектах возбуждения процедуры помилования. Одни авторы считают, что таким субъектом может выступать только осужденный [12, с. $100 ; 5$, с. 104]. Другие предлагают изменить процедуру помилования, допустив рассмотрение ходатайств о помиловании со стороны не только самого осужденного, но и членов семьи, близких родственников, представителей общественных, в первую очередь правозащитных, организаций и т. п. [11, с. 67]. В положении были учтены данные предложения, но только частично. Так, новеллой является то, что обращения о помиловании, поступившие от родственников, адвокатов осужденных, представителей общественных организаций, а также от иных лиц учитываются при рассмотрении ходатайства осужденного о помиловании (подп. «3» п. 21), однако не представляют самостоятельного основания для начала процедуры помилования.

Вполне обоснованно в этом же пункте положения реализовано ранее выдвигавшееся учеными [7, с. 140] предложение о необходимости учета при помиловании мнения потерпевших или их родственников относительно возможности помилования. В настоящее время сделать соответствующий 
запрос можно на всех стадиях прохождения ходатайства о помиловании.

Большие сомнения у профессионального [8, с. 37], научного [14, с. 83] и правозащитного [3, с. 59] сообществ вызывала норма ранее действовавшего положения о том, что список лиц, рекомендованных высшим должностным лицом субъекта Российской Федерации к помилованию, публикуется в СМИ соответствующего субъекта Российской Федерации в месячный срок со дня принятия такого решения. Помимо указания фамилии и инициалов осужденного, рекомендованного к помилованию, также делается ссылка на статью уголовного закона, по которой он осужден. При этом высшее должностное лицо субъекта Российской Федерации могло также обнародовать мотивы, которыми руководствовалось при принятии соответствующего решения. Неоднозначное восприятие данной нормы одними авторами объяснялось тем, что СМИ, имеющие распространение на территории субъекта Российской Федерации, не могут донести информацию о кандидатах на помилование до сведения потерпевших, поэтому такие списки необходимо публиковать также в СМИ субъектов Российской Федерации по постоянному месту жительства осужденного и месту его осуждения [6, с. 146]. Другие авторы видели ущербность этой нормы в том, что списки содержат данные осужденных, рекомендованных высшим должностным лицом к помилованию, но не содержат аналогичных данных тех осужденных, ходатайства которых не поддержаны [9, c. 44-45].

В новом положении такая норма отсутствует, что следует рассматривать как позитивное изменение в порядке рассмотрения ходатайства осужденного о помиловании. Во-первых, учет мнения потерпевших в наш информационный век можно обеспечить не опубликованием статьи УК РФ и анкетных данных лиц, получивших положительную рекомендацию высшего должностного лица субъекта Российской Федерации, а иными методами. Кроме того, это необходимо до принятия решения высшим должностным лицом, а не после.

Во-вторых, существовавшая до 2020 г. норма просто удовлетворяла общественный интерес к деятельности главы субъекта Российской Федерации в обозначенной сфере. Интерес этот вполне оправдан и заслуживает внимательного к себе отношения, однако для удовлетворения его достаточно привести буквенное обозначение фамилии, как это делается при размещении в сети Интернет судебных решений.

В-третьих, такого рода публикация противоречила положениям законодательства о защите персональных данных, поскольку допускала их доведение до неограниченного числа лиц без согласия обладателя, а также п. 16А.3 Европейских пенитенциарных правил (в ред. от 01.07.2020), где установлено, что все сведения об осужденном должны храниться конфиденциально и быть доступными только для тех лиц, чьи профессиональные обязанности требуют этого.

\section{Заключение}

Внесенные указом Президента Российской Федерации от 14.12.2020 № 797 изменения в указ Президента Российской Федерации от 28.12.2001 № 1500 « комиссиях по вопросам помилования на территориях субъектов Российской Федерации» и принятие нового Положения о порядке рассмотрения ходатайств о помиловании в Российской Федерации повысили уровень нормативной регламентации деятельности комиссий и рассмотрения ходатайств осужденных о помиловании. К числу позитивных изменений можно отнести: увеличение срока ротации членов комиссий по вопросам помилования; уточнение их аналитических и контрольных функций; включение социальной адаптации в число обстоятельств, учитываемых при рассмотрении вопроса о помиловании; исключение опубликования в СМИ анкетных данных лиц, рекомендованных к помилованию высшим должностным лицом субъекта Российской Федерации; учет мнения потерпевших от преступления.

В то же время эти нововведения породили проблемы в виде противоречий с нормами уголовного и уголовно-исполнительного законодательства. Речь идет о возможностях применения помилования к лицам, отбывающим иные меры уголовно-правового характера, и обращения с ходатайством о помиловании непосредственно в комиссию по вопросам помилования, минуя администрацию учреждений и органов, исполняющих наказания.

Представляется, что изначально поставленная задача по увеличению числа лиц, к которым применено помилование, едва ли может быть решена в результате принятия новых нормативных актов. 


\section{СПИСОК ЛИТЕРАТУРЫ}

1. Бабушкин, А. В. Выступление на Всероссийском совещании председателей комиссий по вопросам помилования на территориях субъектов Российской Федерации / А. В. Бабушкин /// Всероссийское совещание председателей комиссий по вопросам помилования на территориях субъектов Российской Федерации. - Москва : Юридическая литература, 2003. - С. 85-89. - ISBN 5-7260-1014-0.

2. Банк документов // Официальный сайт Президента Российской Федерации. - URL: http://www.kremlin.ru/acts/ bank (дата обращения: 16.02.2021).

3. Борщев, В. В. Выступление на Всероссийском совещании председателей комиссий по вопросам помилования на территориях субъектов Российской Федерации / В. В. Борщев // Всероссийское совещание председателей комиссий по вопросам помилования на территориях субъектов Российской Федерации (Московская область, Горки-Х, 4-6 декабря 2002 года). - Москва : Юридическая литература, 2003. - С. 58-62. - ISBN 5-7260-1014-0.

4. Головастова, Ю. А. Уголовно-исполнительное право как отрасль российского права: предмет, метод, источники, система : монография / Ю. А. Головастова ; под научной редакцией В. И. Селиверстова. - Москва : Юриспруденция, 2019. - 560 c. - ISBN 978-5-9516-0855-0.

5. Гришко, А. Я. Амнистия. Помилование. Судимость / А. Я. Гришко, А. М. Потапов. - Москва : Логос, 2009. - 272 с. ISBN 978-5-98704-368-9.

6. Гришко, А. Я. Амнистия. Помилование : монография / А. Я. Гришко. - 3-е изд. - Москва : Логос, 2014. - 236 с. ISBN 978-5-98704-790-3.

7. Кавелина, О. Г. Институт помилования: криминологические и уголовно-правовые аспекты : монография / О. Г. Кавелина. - Москва : Юрлитинформ, 2011. - 192 с. - ISBN 978-5-93295-808-7.

8. Калинин, Ю. И. Выступление на Всероссийском совещании председателей комиссий по вопросам помилования на территориях субъектов Российской Федерации / Ю. И. Калинин // Всероссийское совещание председателей комиссий по вопросам помилования на территориях субъектов Российской Федерации (Московская область, Горки-Х, 4-6 декабря 2002 года). - Москва : Юридическая литература, 2003. - С. 31-39. - ISBN 5-7260-1014-0.

9. Малков, В. П. Избранные труды. В 3 томах. Том 1. О некоторых вопросах совершенствования нормативно-правовой базы осуществления помилования в России / В. П. Малков. - Казань : Познание, 2011 - 521 с. - ISBN 978-58399-0397-5.

10. Михлин, А. С. Выступление на Всероссийском совещании председателей комиссий по вопросам помилования на территориях субъектов Российской Федерации / А. С. Михлин // Всероссийское совещание председателей комиссий по вопросам помилования на территориях субъектов Российской Федерации (г. Нижний Новгород, 16-18 декабря 2003 года). - Москва : Юридическая литература, 2004. - С. 91-95. - ISBN 5-7260-1014-0.

11. Михлин, А. С. Федеральный закон «О помиловании» (проект) / А. С. Михлин, В. И. Селиверстов, Л. В. Яковлева // Криминологический журнал. - 2002. - № 2. - С. 67-72.

12. Никитин, Д. А. Помилование: криминологический и уголовно-исполнительный анализ / Д. А. Никитин. - Москва: Юрлитинформ, 2011. - 200 с. - ISBN 978-5-93295-848-3.

13. Петрашев, В.Н.Гуманизация системы наказаний в советском уголовном праве : монография / В. Н. Петрашевя. - Ростов-на-Дону : Ростовский государственный университет, 1988. - 141 с. - ISBN 5-7507-0009-7.

14. Селиверстов, В. И. Выступление на российско-французском научно-юридическом коллоквиуме по проблемам изменений, происходящих в уголовно-исполнительной системе, пенитенциарном законодательстве и международном праве по вопросам помилования / В. И. Селиверстов // Российско-французский научно-юридический коллоквиум по проблемам изменений, происходящих в уголовно-исполнительной системе, пенитенциарном законодательстве и международном праве по вопросам помилования (г. Москва, 29-30 мая 2003 года). - Москва : Юридическая литература, 2003. - С. 82-84. - ISBN 5-7260-1015-9.

15. Селиверстов, В. И. Уголовно-правовые и уголовно-исполнительные проблемы условно-досрочного освобождения / В. И. Селиверстов // Уголовное право. - 2015. - № 3. - С. 97-101.

\section{REFERENCES}

1. Babushkin A.V. Speech at the all-Russian meeting of the chairmen of the commissions on issues of pardon in the territories of constituent entities of the Russian Federation. Vserossiiskoe soveshchanie predsedatelei komissii po voprosam pomilovaniya na territoriyakh sub"ektov Rossiiskoi Federatsii [All-Russian meeting of the chairmen of the commissions on issues of pardon in the territories of constituent entities of the Russian Federation]. Moscow: Yuridicheskaya literatura, 2003. Pp. 85-89. (In Russ.).

2. Documents database. Official website of the President of the Russian Federation. Available at: http://www.kremlin.ru/ acts/bank (accessed February 16, 2021). (In Russ.).

3. Borshchev V.V. Speech at the all-Russian meeting of the chairmen of the commissions on issues of pardon in the territories of constituent entities of the Russian Federation. Vserossiiskoe soveshchanie predsedatelei komissii po voprosam pomilovaniya na territoriyakh sub»ektov Rossiiskoi Federatsii (Moskovskaya oblast', Gorki-Kh, 4-6 dekabrya 2002 goda) [All-Russian meeting of the chairmen of the commissions on issues of pardon in the territories of constituent entities of the Russian Federation (Moscow Oblast, Gorky-10, December 4-6, 2002)]. Moscow: Yuridicheskaya literatura, 2003. Pp. 58-62. (In Russ.).

4. Golovastova Yu.A. Ugolovno-ispolnitel'noe pravo kak otrasl' rossiiskogo prava: predmet, metod, istochniki, sistema: monografiya [Penal law as a branch of Russian law: subject, method, sources, system. A monograph]. Under scientific editorship of V.I. Seliverstov. Moscow: Yurisprudentsiya, 2019. 560 p.

5. Grishko A.Ya., Potapov A.M. Amnistiya. Pomilovanie. Sudimost' [Amnesty. Pardon. Criminal record]. Moscow: Logos, 2009. 272 p.

6. Grishko A. Ya. Amnistiya. Pomilovanie: monografiya [Amnesty. Pardon. A monograph]. 3rd edition. Moscow: Logos, 2014. 236 p.

7. Kavelina O.G. Institut pomilovaniya: kriminologicheskie i ugolovno-pravovye aspekty: monografiya [Institute of pardon: criminological and criminal-legal aspects. A monograph]. Moscow: Yurlitinform, 2011. 192 p.

8. Kalinin Yu.I. Speech at the all-Russian meeting of the chairmen of the commissions on issues of pardon in the territories of constituent entities of the Russian Federation. Vserossiiskoe soveshchanie predsedatelei komissii po voprosam 
pomilovaniya na territoriyakh sub»ektov Rossiiskoi Federatsii (Moskovskaya oblast', Gorki-Kh, 4-6 dekabrya 2002 goda) [All-Russian meeting of the chairmen of the commissions on issues of pardon in the territories of constituent entities of the Russian Federation (Moscow Oblast, Gorky-10, December 4-6, 2002)]. Moscow: Yuridicheskaya literatura, 2003. Pp. 3139. (In Russ.).

9. Malkov V.P. Izbrannye trudy. V 3 tomakh. Tom 1. O nekotorykh voprosakh sovershenstvovaniya normativno-pravovoi bazy osushchestvleniya pomilovaniya $v$ Rossii [Selected works. In 3 volumes. Volume 1. On some issues of improving the legal framework for the implementation of pardons in Russia]. Kazan: Poznanie, 2011521 p.

10. Mikhlin A.S. Speech at the all-Russian meeting of the chairmen of the commissions on issues of pardon in the territories of constituent entities of the Russian Federation. Vserossiiskoe soveshchanie predsedatelei komissii po voprosam pomilovaniya na territoriyakh sub»ektov Rossiiskoi Federatsi (g. Nizhnii Novgorod, 16-18 dekabrya 2003 goda) [AllRussian meeting of the chairmen of the commissions on issues of pardon in the territories of constituent entities of the Russian Federation (Nizhny Novgorod, December 16-18, 2003)]. Moscow: Yuridicheskaya literatura, 2004. Pp. 91-95. (In Russ.).

11. Mikhlin A.S., Seliverstov V.I., Yakovleva L.V. Federal law "On pardon" (draft). Kriminologicheskii zhurnal=Journal of Criminology, 2002, no. 2, pp. 67-72. (In Russ.).

12. Nikitin D.A. Pomilovanie: kriminologicheskii i ugolovno-ispolnitel'nyi analiz [Pardon: criminological and penal analysis]. Moscow: Yurlitinform, 2011. 200 p.

13. Petrashev V.N. Gumanizatsiya sistemy nakazanii v sovetskom ugolovnom prave: monografiya [Humanization of the system of punishments in Soviet criminal law. A monograph]. Rostov-on-Don: Rostovskii gosudarstvennyi universitet, 1988. $141 \mathrm{p}$.

14. Seliverstov V.I. Speech at the Russian-French scientific and legal colloquium on the problems of changes occurring in the penal system, penitentiary legislation and international law on issues of pardon. Rossiisko-frantsuzskii nauchnoyuridicheskii kollokvium po problemam izmenenii, proiskhodyashchikh v ugolovno-ispolnitel'noi sisteme, penitentsiarnom zakonodatel'stve i mezhdunarodnom prave po voprosam pomilovaniya ( $g$. Moskva, 29-30 maya 2003 goda) [RussianFrench scientific and legal colloquium on the problems of changes occurring in the penal system, penitentiary legislation and international law on issues of pardon (Moscow, May 29-30, 2003)]. Moscow: Yuridicheskaya literatura, 2003. Pp. 8284. (In Russ.).

15. Seliverstov V.I. Criminal-legal and penal issues of release on parole. Ugolovnoe pravo=Criminal Law, 2015, no. 3, pp. 97-101. (In Russ.).

\section{СВЕДЕНИЯ ОБ АВТОРЕ / INFORMATION ABOUT THE AUTHOR}

ВЯЧЕСЛАВ ИВАНОВИЧ СЕЛИВЕРСТОВ - ДОКТОр ЮрИдических наук, профессор, заслуженный деятель науки Российской Федерации, профессор кафедры уголовного права и криминологии Московского государственного университета им. М. В. Ломоносова, профессор кафедры уголовно-правовых дисциплин Московского государственного лингвистического университета, г. Москва, Российская Федерация. ORCID: https://orcid. org/0000-0002-9554-5438, e-mail: vis_home@list.ru
VYACHESLAV I. SELIVERSTOV - Doctor of Sciences (Law), Professor, Honored Scientist of the Russian Federation, professor of the Department of Criminal Law and Criminology of Lomonosov Moscow State University; professor of the Department of Criminal Law Disciplines of Moscow State Linguistic University, Moscow, Russian Federation. ORCID: https://orcid.org/0000-0002-95545438, e-mail: vis_home@list.ru 